\title{
Improvement of teacher's professional competency in strengthening learning methods to maximize curriculum implementation
}

\author{
Hendro Prasetyono ${ }^{1}$, Agus Abdillah ${ }^{2}$, Tjipto Djuhartono ${ }^{3}$, Ira Pratiwi Ramdayana ${ }^{4}$ Laila Desnaranti $^{5}$ \\ 1,2,3,5 Department of Economics Education, Universitas Indraprasta PGRI, Indonesia \\ ${ }^{4}$ Department of Indonesian Language Education, Universitas Indraprasta PGRI, Indonesia
}

\begin{tabular}{|c|c|}
\hline Article Info & ABSTRACT \\
\hline Article history: & The 2013 curriculum which has been implemented for more than six years in \\
\hline Received Oct 14, 2020 & Indonesia has many problems in its application. Therefore, we need to \\
\hline Revised Mar 10, 2021 & implementation of the 2013 curriculum in schools. This study involved 13 \\
\hline Accepted Apr 17, 2021 & $\begin{array}{l}\text { high schools and vocational high schools in the provinces of DKI Jakarta and } \\
\text { West Java with a total of } 420 \text { students, } 26 \text { teachers, and principals as }\end{array}$ \\
\hline Keywords: & $\begin{array}{l}\text { respondents. The research employed mixed parallel method and data analysis } \\
\text { using combined analysis of qualitative and quantitative approaches. The }\end{array}$ \\
\hline High school & research found that there are still schools that use two different curricula, \\
\hline Implementation curriculum & $\begin{array}{l}2013 \text { curriculum and school-based curriculum. In implementing the } 2013 \\
\text { curriculum, teachers are required to use various learning with a scientific }\end{array}$ \\
\hline Learning methods & approach that refers to student-centered concepts. There is a need for the \\
\hline Mixed-method & training program to improve teachers' professional competence, especially in \\
\hline Professional compet & the terms of various learning methods mastery. \\
\hline
\end{tabular}

This is an open access article under the $\underline{C C B Y-S A}$ license.

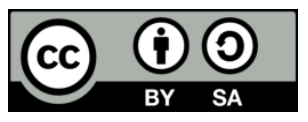

\section{Corresponding Author:}

Hendro Prasetyono

Department of Economics Education

Universitas Indraprasta PGRI

Tengah Street, Number 80, Gedong, DKI Jakarta, Indonesia

Email: hendro_prasetyono@unindra.ac.id

\section{INTRODUCTION}

Curriculum implementation has to be applied with communication and socialization which is appropriate and well targeted. This is needed to achieve the educational purposes which are done while learning is delivered to the students [1]. Seeing the students' and teachers' perceptions while learning is one of the ways that can be used to know the success of a curriculum implementation [2]. However, nowadays there are still many policymakers in a country seeing the success in curriculum implementation from graduates' quality and learning achievement aspects without seeing the students' and teachers' perception in the learning process [3], [4].

Currently, Indonesia is implementing the 2013 curriculum which has been used for seven years and four-time revised because the learning purposes considered have not been successful. Based on a grand tour result in October 2019 which is done by the researcher team to eight junior high schools, it was discovered that many students complained about the learning process in class. The students who complained said only students were asked to present but lack of explanation from the teachers. The discovery can be defined that the teachers are not effective and have not mastered the variation of learning method [5]. The mastery of 
teachers' professional competencies must be increased to achieve the learning target. Optimal learning outcomes are the ideals or dreams to be achieved by stakeholders [6].

Learning targets in the 2013 curriculum is not only competence achievement but also students' character building. The implementation of characters education in the 2013 curriculum can be done through the process of integrating learning achievements, synergizing the role of educational institutions, teachers manifesting themselves as competent and emulated teachers [7]. Teachers design curriculum materials and how they engage with their material resourcing curriculum activities. It occurs that the 2013 curriculum is impressive if it is implemented properly. Other causes that become obstacles in the implementation of the 2013 Curriculum come from the government, institutions, teachers, parents, and students [8]. The main factor that played an important role in the successful implementation of the 2013 Curriculum was teacher readiness. It needed an effort from the government to overcome this therefore the teachers are prepared better to carry out the teaching and learning process following the curriculum.

Based on some survey results from previous research, it is known that quite a lot of elementary, junior high, and high school teachers have difficulty using the 2013 curriculum in class because of their limited ability to use learning methods [8], [9]. Obstacles faced by the teachers include the instructional media creating, teachers' understanding, subject content integration in thematic learning, and information technology proficiency. Therefore, training as a teaching practice and learning media proficiency are needed to understand the essence of the 2013 curriculum to overcome these obstacles. As part of the main competencies, the teachers' professional competence becomes an important focus especially for the teachers as the person to implement the curriculum. This means that there is a need for developing teachers' professional competence especially about the teaching and learning process in the classroom.

The Ministry of Education and Culture evaluated the 2013 Curriculum in mid-2019. This is due to the 2013 Curriculum which includes character building, competence, and nationalism in its implementation, also using contextualizing learning is still a challenge. There are still high school teachers in the DKI Jakarta and West Java provinces who do not understand the learning process in the 2013 curriculum. Development of the 2013 curriculum in education, especially in vocational education is carried out to be able to approach and meet the needs of the business and industrial world. The government needs to make various efforts to improve the teaching quality of the teachers to solve this problem [10].

Nowadays the most important indicator for teacher education quality is the teacher's professional competence which is a demand within the era of postmodernism [11]. The government through school can improve teachers' competency through training about how to teach correct practices so that not only teaching material quality developed but also the teaching methods quality for teaching practices. However, it is necessary to be more specific on what training is appropriate to improve the quality of the 2013 Curriculum implementation because the competencies that have to be owned by teachers are pedagogical, personal, professional, and social competencies. We need an empirical study for the implementation of the 2013 Curriculum to find out the level of achievement and obstacles from the learning process experienced by the teachers.

Curriculum of 2013 emphasizes authentic assessments which include performance, project, portfolio, process, and self-assessment [8]. It can be concluded that learning using 2013 Curriculum focuses on the level of material understanding, how to deliver the material, and student center. The research objective of this article is to determine the curriculum implementation condition in senior high and vocational schools in Indonesia. When it comes to schooling and the role of school teachers in bringing about change to the curriculum, the question needs to be answered of what sort of knowledge and abilities teachers need to acquire to become active change agents and what role teacher education can play in contributing to the development of these competencies [12]. The teacher competency has moved from a narrow technical skillsbased focus to a broader and more holistic concept of building pedagogical knowledge about technology including both instructional tools and cognitive tools to foster student learning [13].

The teacher's professional competence is the proficiency of extensive and in-depth learning material, which includes the subject curriculum materials mastery in schools and the scientific substance that houses the material, as well as the science structure and methodology mastery [12]. Teacher professional competencies can be categorized as: 1) Understanding the competency standards and basic competencies in their fields of expertise; 2) Able to choose and develop subject matter; 3) Understanding the material, structure, and concept of scientific thought patterns that support the field of expertise; 4) Master the methods for developing critical knowledge and studies related to the field of expertise; 5) Creative and innovative in the application of scientific fields related to the field of expertise; 6) Able to develop curriculum and syllabus related to the field of expertise; 7) Able to take reflective actions to improve the quality of learning; 8) Able to communicate with the professional community itself and other professions verbally and written; 9) Able to utilize information and learning technology; 10) Communicate and develop themselves as a teacher [14]. 
Teachers' professional competence help desk was available for the leaders to ask questions regarding the curriculum and technology that supported implementation [15]. A professional teacher can master learning material in a broad and in-depth field of study which includes the substance of curriculum subject matter content proficiency in schools and the scientific substance that houses the curriculum material, as well as adding scientific insights as a teacher [16]. Personal characteristics of the professional care groups were the most important variables associated with the quality of the care. On the other hand, professional standards and have adopted as a criterion the functions and roles of beginning teachers, the following general professional competencies have been derived: cognitive and meta-cognitive, methodological, communicative and relational, student evaluation, psychosocial, informational and technological, career management competencies [17]. Currently, in the era of postmodernism, a professional teacher must be mastering a variety of learning methods by involving digitalization in teaching [11]. Based on this, the purpose of the study is to determine the cause of the ineffective 2013 curriculum implementation in schools as a recommendation for the government to determine appropriate policies in increasing teacher competence.

\section{RESEARCH METHOD}

This research used mixed methods because to answer the problems in this study, triangulation is needed. Triangulation in this study comes from interviews, study documents, questionnaires, and observation data. The type of mixed methods chosen is parallel mixed methods which mean involve the collection, analysis, and integration of quantitative and qualitative data in a single or multiphase study [18].

The study was conducted from October 2019 to January 2020 involving 13 high schools consist of four public vocational high schools, six private vocational schools, two public senior high schools, and one private high school. Research designs consist of the concurrent mixing of qualitative and quantitative methods carried out as separate studies within the same research project, with the qualitative component taking a more dominant role [18]. A quantitative approach is done at the very start of the research by spreading questionnaires to the respondents [19]. A quantitative approach is used to determine conditions in schools that implementing the 2013 Curriculum from the student's perspective from what they felt during the learning process. The result of the questionnaire then expands by using the qualitative method which is observation and interview to the respondents, teacher, and students [20].

The population which the researchers can reach in this study were students from four Public Vocational High Schools, six Private Vocational Schools, two Public Senior High Schools, and one Private Vocational High Schools that are in DKI Jakarta and West Java Province. The schools are 7 Bekasi, 62 Jakarta, 51 Jakarta, and 41 Jakarta Public Vocational High School. For the Private Vocational High School are Mutiara Depok, 3 Cikini College Jakarta, Wijaya Kusuma Islamic Vocational High School Depok, Islamic Malahayati Jakarta, PGRI 28 Jakarta, and Al-Basyariah Bogor. The public senior high schools are 13 Depok and 10 Depok, also Uswatun Hasanah Jakarta private high school. The sampling technique uses quota sampling because each school has a sample size of 30 to 35 people depending on the number of all students at the school [21].

The quantitative data was taken by using a closed questionnaire which has four or five choices [22]. The closed questionnaire for descriptive data was compiled based on the 2013 curriculum implementation indicators taken from the Regulation of the Minister of Education and Culture of the Republic of Indonesia No. 81A of 2013 [23]. The validity and reliability of the questionnaire used an expert test which meant that after the questionnaire was compiled, it was consulted with experts [24]. The quantitative approach is used to determine the student's perception of the learning implementation using the 2013 Curriculum by distributing questionnaires. Item statement and choice of answers in the questionnaire can be seen in Table 1 .

Table 1. Questionnaire statements for students

\begin{tabular}{|c|c|c|}
\hline No & Statement & Answer choice \\
\hline 2 & The teacher method for presenting the material & $\begin{array}{l}\text { (a) Easy to understand, very interesting, and very fun; (b) Easy to } \\
\text { understand, but less interesting and less pleasant; (c) Difficult to } \\
\text { understand, but interesting and fun; (d) Difficult to understand, less } \\
\text { interesting and less pleasant }\end{array}$ \\
\hline 3 & $\begin{array}{l}\text { The teacher gives the opportunity to observe, ask } \\
\text { questions, collect data, reason, and communicate }\end{array}$ & $\begin{array}{l}\text { (a) Always give a chance; (b) Often gives a chance; (c) Sometimes it } \\
\text { gives a chance; (d) Never give a chance }\end{array}$ \\
\hline 5 & $\begin{array}{l}\text { The teacher explains using how many learning } \\
\text { methods in each meeting }\end{array}$ & (a) 4 methods; (b) 3 methods; (c) 2 method; (d) 1 method \\
\hline
\end{tabular}

Int J Eval \& Res Educ, Vol. 10, No. 2, June 2021: 720 - 727 
A qualitative approach is used to dig deeper from the teacher's and principals' perspective regarding the implementation of the 2013 curriculum by involving 26 key informants consisting of one principal and one teacher each school from 13 schools in DKI Jakarta and West Java Provinces. A qualitative approach is used to obtain more in-depth information in determining the conditions of implementation or events in the environment [25]. Qualitative researchers focus on the study of social phenomena and on giving voice to the feelings and perceptions of the participants under study [26]. Data collection techniques using interviews and direct observation in schools. The questions in the interview include the curriculum used by the school, curriculum development principles, curriculum drafting team, learning methods used at school, curriculum content. the key information is the principal, teacher, vice-principal, curriculum team, students.

Processing data analysis used a combined analysis of qualitative and quantitative approaches. Qualitative data analysis used data triangulation and quantitative data analysis using descriptive analysis. Descriptive research is one form of research that aims to describe the event of the occurrence of the variable in the study [27]. Quantitative data was obtained from spreading closed questionnaire to know the perception which felt by the students in the learning process [28]. Quantitative data analysis by describing the result of the choice from the respondents in percentage, highest, and lowest score. Qualitative data processing used analysis of the reduction and selection stages then assemble blocks or groups of data and putting them together to make a coherent whole [29]. Qualitative data gained from the interview result with the key informant [30]. The selection of key informants has based on the researcher's consideration that the respondents are individuals who are leaders or experts or have a direct relationship with the research topic [31]. Every answer from the respondents processed in the form of coding then merged in one taxonomic or part in answering the problem formulation [32].

\section{RESULTS AND DISCUSSION}

The recapitulation of questionnaires from 420 students as respondents was analyzed with a quantitative approach using descriptive methods. The results of the questionnaire recapitulation are:

a. The level of understanding of the material delivered by the teacher

The result that 344 students $(81.9 \%)$ answered choice (B), most $(\geq 76 \%)$ understood. There are 57 (13.57\%) students choose (C) the majority $(\geq 76 \%)$ did not understand. Choice (A) "I fully understand" $(100 \%)$ a total of $16(3.81 \%)$ students. If examined partially it turns out that choice (B) is the most chosen from respondents occurring in high schools and vocational schools both public and private.

b. The way the teacher presents the material

The result is 163 students $(38.81 \%)$ choose (B) Easy to understand, but less interesting and less enjoyable. Choices (A) an Easy to understand, very interesting, and very enjoyable only choose by 138 (32.86\%) students. Choice (C) Difficult to understand, but interesting and enjoyable choose by 93 (22.14\%) students and choice (D) Difficult to understand, less interesting and less pleasant is $26(6.19 \%)$ students. If examined partially it turns out that choice (B) is the most chosen from respondents occurring in high schools and vocational schools both public and private.

c. The teacher gives an opportunity to observe, ask questions, collect data, reason, and communicate

The result is 206 students $(49.05 \%)$ choose (A) always giving opportunity. Option (B) often gives a chance choose by $139(33.1 \%)$ students. Option (C) sometimes gives a total of $74(17.62 \%)$ students a chance. If examined partially at each school the choice of answers from each student is relatively the same. Most students choose the point (A) as the answer.

d. The way the teacher assigns learning tasks (such as project assignments, problem-solving, or discovery)

The result is 316 students $(75.24 \%$ ) choose (B) as a large easily understood. Choice (C) is most difficult to understand that choose by 84 (20\%) students. The choice (A) easily understood which choose by $19(4.52 \%)$ students. If examined partially it turns out that choice B becomes the most chosen by respondents occurring in high schools and vocational schools both public and private.

e. The teacher in explaining using how many learning methods in each meeting

The result is 191 students (45.48\%) answered the choice of (C) two methods. Choice (B) three methods choose by $164(39.05 \%)$ students. Elective (A) four methods it chooses by $36(8.57 \%)$ students. If analyzed more deeply, private school students choose (C) as many as 108 students out of a total of 191 students compared to state schools totaling 83 students.

The results of interviews with 26 respondents consisting of teachers and representatives of the curriculum were analyzed using a qualitative approach with the tabulation and reduction methods [29]. The results of data reduction are: 
a. Curriculum used by schools

There were 22 respondents answered using the 2013 curriculum and four respondents answered coming from two state high schools still using the 2013 curriculum and School-based Curriculum. Class X and XI have used the 2013 curriculum but class XII is still a School-based Curriculum. This is because class XII has used the School-based Curriculum since the beginning of class X. Aside from this, the use of two curriculums is caused by the teacher's inadequacy in using the 2013 curriculum and the limited facilities also infrastructure. The 2013 curriculum was used in 12 different schools. There are eight schools used 2013 revised 2016 curriculum and four schools used the 2018 revised curriculum. The results of observations showed that 10 schools implement the Zuhr prayer for Muslims, each Vocational School already has a business unit, teachers are close to students and teachers are very disciplined in dress and attendance. The remaining two schools have teachers with low on-time attendance rates and the other two teachers tend not to be eager to teach.

b. Curriculum development principles

There are 24 respondents from 12 schools responded to the Ministry of Education and Culture or followed the government through the Indonesian National Work Competency Standard. There are two schools which are vocational schools answered following the development of the industrial world. The obstacle that arises is that teachers do not understand how to develop a curriculum. The 2013 curriculum is always being revised, and most teachers do not understand the curriculum development. Teachers only get socialization from the government regarding the 2013 curriculum-based learning mechanism.

c. Curriculum drafting team

Senior high schools involve principals, curriculum staff, and representatives' teachers in curriculum preparation. Vocational high schools involve principals, curriculum staff, representatives' teachers, heads of departments, and supervisors in the preparation of the curriculum. The curriculum preparation team members are the same for both public and private schools. The obstacles that arise in the team are the unpreparedness of teachers in facing the 2013 curriculum which is always changing in Human Resources and Infrastructure. The School-based Curriculum has not been completed yet by the government and it updated to the 2013 Curriculum. The 2013 curriculum has not yet been completed, the understanding in the implementation process has been revised again to the 2013 revised Curriculum. While it constraints on facilities and infrastructure for learning equipment such as projectors, classes, also labs which still need to be added and equipped.

d. Learning methods used in school

The high school uses discussion learning methods, experiments, presentations, problem-based learning, lecture methods, inquiry learning, discovery learning, and a scientific approach. Whereas vocational schools using project-based learning methods, presentations, problem-based learning, lecture methods, practice, inquiry learning, and discovery learning. Based on the results of the observation which it can be noted that almost all high schools still use the lecture and discussion methods as the main method of learning and infuse it with experimentation, presentation, or problem-based learning methods. The teacher who uses the discussion method in teaching begins with the student's presentation then the student is left on a long discussion without giving direction and explanation of the in-depth material. Consequently, it looks students are still confused about understanding the material. Whereas vocational high schools have used more problem-based learning and experiment methods.

e. Curriculum content

High schools have the following curriculum structure: general subjects, specialization subjects, cross interests, and local content. The vocational high school has the following curriculum structure: national subjects, regional subjects, productive subjects with the basic fields of expertise $\mathrm{C} 1, \mathrm{C} 2$, and $\mathrm{C} 3$. The analysis started with the answer from question number one where the respondent showed that the students' majority $(81.90 \%)$ understood the material which teaches by the teachers. In a glace, this situation looks good but the learning purpose achievement can not only be seen from learning outcome [33]. The learning process is also one of the important aspects of the achievement of education purposes [34]. One of the learning process components which has to be paid attention to is the teachers' teaching method in the class.

The answer from question number two that is respondents showed teachers' methods in teaching were not interesting. Based on the interview with the students, the researchers found out that in teaching teachers only gave students tasks to draft paper in groups and then explained in front of the class. The phenomenon that occurs while participant observation is that the teacher uses the student center approach when the teacher leaves students free to discuss. In the learning process, especially in high school students are allowed to engage in long discussions that do not end. When referring to the concept of the 2013 curriculum student center, the teacher as a facilitator must be creative in guiding students to be in the right flow of the learning process. Many teachers are still afraid to be creative and innovative in teaching activities and don't move out of the prescribed curricula. A curriculum is still seen as a subject matter to be completed 
in each academic session [35]. Mastery of diverse learning methods in addition to increasing the effectiveness of teaching can also eliminate the boredom experienced by students during learning.

The answer to question number three showed that teachers have given their students opportunities to question, observe, and give an opinion. It means that teachers in teaching have shown innovative behavior to increase the students' creativity and self-confidence [36]. Teachers' innovative behavior in teaching, one of it often shares their knowledge with their fellow teachers, even though the interview result with the school principals and teachers also participants observation narrowed that most of the teachers are not able to move from the conventional method when using the previous curriculum (school-based curriculum and competency-based curriculum). This learning method is called the discussion learning method. The success of this method must be accompanied by the teacher's role as a facilitator in the class [37]. The teacher must be active as a "referee" in the learning process if the discussion is out of direction. The interview results showed that the teachers already knew if they taught with the 2013 curriculum, they must use these approaches and methods. However, they were lacking or not mastering the methods so they still used the lecture and presentation methods. Besides, there are still two schools using two curricula, but their teaching style is still referred to in the previous curriculum. This was supported by the results from the fifth statement questionnaire summary which contained the majority of respondents choose the teachers' using only two learning methods and the teacher using four learning methods is the smallest amount. This is of course very different from the purpose of the 2013 curriculum which emphasized creativity and innovation. Creativity and innovation are needed to achieve the learning purposes in this era. [38].

The answers in question number 4 are the way teachers give tasks to their students is easy to understand. This means that teachers quite a success in communicating the learning material, tasks, and encourage the students to be active in the learning process. The majority of the respondents said that teachers in teaching used the student center approach because it is not easy [39]. One of the factors causing this to happen is that teachers are not able to create a student-centered environment [40]. In the student-centered environment, teachers provide the learning opportunity (e.g. issues, cases, or problems), and then facilitate learning, while students determine the engagement and production nature of learning outcomes, after that, they formulate plans and carry out those plans in developing products and outputs [41]. However, the need also exists to enhance teachers' abilities to implement learner-centered education philosophy in the classroom.

The answers in question number 5 from the majority of the respondents are even though all schools have used the 2013 Curriculum, the implementation needs to be analyzed in schools. The curriculum implementation form in schools is the teaching and learning process in the class [42]. Teachers who use the curriculum as a guide will produce good students' understanding levels. The teaching style factor and the instructional media choice become one of the influential factors in the level of students' understanding of learning [43]. The curriculum is seen with great significance by teachers in any education system as it often serves as a rule book for teachers [35]. Even though there is a learning method that appropriates with 2013 curriculum such as Jigsaw, project-based learning methods, presentations, problem-based learning, lecture methods, practice, inquiry learning, and discovery learning [44]-[46].

Another more specific finding is that there are quite a several teachers who have not mastered learning methods which use computers and the internet, like using videos or making vlogs that are very popular with young people today. Teachers' demographic factors, such as level educations and age, have been discussed in the research literature concerning whether and to what extent they influence the use of ICT in the class [47]. Research has shown that nowadays students are technophile. They love video games and can't put down their smartphones, iPods, or social networks. Consequently, it is necessary to improve the teacher's professional competence in using learning resources and learning methods to improve the implementation quality of the 2013 curriculum.

\section{CONCLUSION}

The findings of this study are the curriculum implementation in Indonesia is still not maximal and there is a curriculum dualism in schools. There are still schools that use a competency-based curriculum, even though the 2013 curriculum has been legalized for a long time to be used in schools. The cause of the 2013 curriculum's ineffective implementation at the senior and vocational high schools in Indonesia is the teachers' professional competency which must be improved. These findings occur to the teachers in senior and vocational high schools who were taken as a sample from the research location.

Teachers must master the project-based learning method, problem-based learning, lecture methods, practice, inquiry learning, discovery learning with a scientific approach that refers to the student center. It is necessary to support the successful implementation of the 2013 curriculum that aims to create human beings with character. Various learning methods mastery needs to be strengthened by the teacher's ability to utilize 
learning resources that come from the internet. Also, for suggestions, there needs to be an education and training management that facilitates the needs of teachers in mastering diverse learning methods. It can be included in Teacher Professional Education (TPE) or related private institutions that can carry out the training. The limitation of this study is the research only covers schools of three provinces in Indonesia. Also, it has not yet reached a recommendation for an appropriate training model to be used as a guide to improving teachers' professional competence.

\section{REFERENCES}

[1] S. L. Zorluoğlu, T. Ergazi, and Ş. Eser, "Learning Probability of 4th Grade Science Curriculum Learning Outcomes Among Visually Impaired Students," Int. J. Eval. Res. Educ. (IJERE), vol. 8, no. 3, pp. 417-424, 2019.

[2] M. S. Chiu and D. Whitebread, "Taiwanese Teachers' Implementation of A New 'Constructivist Mathematics Curriculum': How Cognitive and Affective Issues are Addressed,” Int. J. Educ. Dev., vol. 31, no. 2, pp. 196-206, 2011

[3] Y. Kirkgöz, "A Case Study of Teachers' Implementation of Curriculum Innovation in English Language Teaching in Turkish Primary Education," Teach. Teach. Educ., vol. 24, no. 7, pp. 1859-1875, 2008.

[4] N. D. Usta, Z. Ceng, F. Kasli, and A. Ayas, "Evaluation of Implementation of Compounds Unit at 9th Grade in The New Chemistry Curriculum," Procedia - Soc. Behav. Sci., vol. 1, no. 1, pp. 2359-2362, 2009.

[5] L. D. V. Rubenstein, L. M. Ridgley, G. L. Callan, S. Karami, and J. Ehlinger, "How Teachers Perceive Factors that Influence Creativity Development: Applying a Social Cognitive Theory Perspective," Teach. Teach. Educ., vol. 70, pp. 100-110, 2018.

[6] H. Prasetyono, A. Abdillah, T. Anita, A. Nurfarkhana, and A. Sefudin, "Identification of the Decline in Learning Outcomes in Statistics Courses Using the Chi-Squared Automatic Interaction Detection Method," J. Phys. Conf. Ser., vol. 1490, pp. 1-9, 2020.

[7] A. D. S. Krissandi and Rusmawan, "Constraints for Primary School Teachers in Implementing The 2013 Curriculum," Cakrawala Pendidik., vol. 34, no. 3, pp. 457-467, 2015.

[8] Y. Natsir, Y. Q. Yusuf, and U. F. Nasution, "The Rise and Fall of Curriculum 2013: Insights on the Attitude Assessment from Practicing Teachers," SHS Web Conf., vol. 42, p. 00010, 2018

[9] W. Maba and I. B. N. Mantra, "The Primary School Teachers' Competence in Implementing The 2013 Curriculum," SHS Web Conf., vol. 42, no. 35, pp. 1-7, 2018.

[10] Y. Nora, "Learning of Social Studies in Elementary School as a Medium to Strengthen Multicultural Education in The Curriculum Era 2013," SHS Web Conf., vol. 42, no. 94, pp. 1-7, 2018.

[11] I. S. Naydenova and N. N. Naydenova, "Teacher's Electronic Portfolio in Professional Standard of Teacher," SHS Web Conf., vol. 29, no. 01052, pp. 1-5, 2016.

[12] L. Bürgener and M. Barth, "Sustainability Competencies in Teacher Education: Making Teacher Education Count in Everyday School Practice," J. Clean. Prod., vol. 174, pp. 821-826, 2018.

[13] J. Tondeur, K. Aesaert, S. Prestridge, and E. Consuegra, "A Multilevel Analysis of What Matters in The Training of Pre-Service Teacher's ICT Competencies,” Comput. Educ., vol. 122, pp. 32-42, 2018.

[14] M. Sirotová, "Pedagogical Praxis as A Process Of Developing Professional Competencies In University Education Of Future Teachers,” Procedia - Soc. Behav. Sci., vol. 228, pp. 529-534, Jun. 2016.

[15] L. Franzen-Castle, et al., "Development of the iCook 4-H Curriculum for Youth and Adults: Cooking, Eating, and Playing Together for Childhood Obesity Prevention," J. Nutr. Educ. Behav., vol. 51, no. 3, pp. S60-S68, 2019.

[16] S. Syahrial, et al., "The impact of etnocontructivism in social affairs on pedagogic competencies," Int. J. Eval. Res. Educ. (IJERE), vol. 8, no. 3, pp. 409-416, 2019.

[17] E. Ciucci, A. Baroncelli, M. Toselli, and S. A. Denham, "Personal and Professional Emotional Characteristics of Early Childhood Teachers and Their Proneness to Communicate With Parents and Colleagues About Children's Emotions," Child Youth Care Forum, vol. 47, no. 2, pp. 303-316, 2018.

[18] S. H.-B. Nagy, Mixed Methods Research. New York: The Guilford Press, 2010.

[19] C. R. Ember and M. Ember, Cross-cultural Research Methods, 2nd ed. New York: Altamira, 2009.

[20] D. Scott and M. Morrison, Key Ideas in Educational Research. New York: Continuum International, 2005.

[21] P. Dattalo, Determining sample size. Oxford: Oxford University Press, 2008

[22] S. Presser, et al., "Methods for Testing and Evaluating Survey Questions," Public Opinion Quarterly, vol. 68, no. 1, pp. 109-130, 2004

[23] M. Nuh, Implementation of Curriculum in Indonesia. Indonesia, 2013.

[24] W. A. Fuller, Sampling statistics. New Jersey: A John Wiley \& Sons, Inc, 2009.

[25] H. Prasetyono, "Graduate Program Evaluation in the Area Leading Educational, Outlying and Backward," J. Educ. Pract., vol. 7, no. 36, pp. 109-116, 2016.

[26] M. G. Lodico, D. T. Spaulding, and K. H. Voegtle, Methods in Educational Research : From Theory to Practice. Jossey-Bass, 2006.

[27] H. Prasetyono, A. Abdillah, T. Widiarto, and H. Sriyono, "Character-based Economic Learning Implementation and Teacher's Reinforcement on Student's Affective Competence in Minimizing Hoax," Cakrawala Pendidik., vol. 37, no. 3, pp. 426-435, 2018.

[28] L. Cohen, L. Manion, and K. Morrison, Research Methods in Education, 6th Ed. New York: Routledge, 2007.

Int J Eval \& Res Educ, Vol. 10, No. 2, June 2021: 720 - 727 
[29] A. Matthew B. Miles and M. Huberman, Qualitative Data Analysis: An Expanded Sourcebook, 2nd Ed. California: SAGE Publications, Inc, 1994.

[30] K. Singh, Quantitative Social Research Methods. Los Angeles: SAGE Publications, 2007.

[31] G. Lancaster, Research Methods in Management. Amsterdam: Elsivier, 2005.

[32] R. E. Stake, Qualitative Research: Studying How Things Work. New York: The Guilford Press, 2010.

[33] R. Seebruck, "Teacher Quality and Student Achievement: A Multilevel Analysis of Teacher Credentialization and Student Test Scores in California High Schools," Mcgill Sociol. Rev., vol. 5, no. July, pp. 1-18, 2015.

[34] X. Xuan, et al., "Relationship Among School Socioeconomic Status, Teacher-Student Relationship, and Middle School Students' Academic Achievement in China: Using The Multilevel Mediation Model," Plos One J., pp. 1-17, 2019.

[35] I. Umami, "Moderating Influence of Curriculum, Pedagogy, and Assessment Practices on Learning Outcomes in Indonesian Secondary Education," J. Soc. Stud. Educ. Res., vol. 9, no. 1, pp. 60-75, 2018.

[36] J. Nasongkhla and S. Sujiva, "Teacher Competency Development: Teaching with Tablet Technology through Classroom Innovative Action Research (CIAR) Coaching Process," in Procedia - Social and Behavioral Sciences, vol. 174, pp. 992-999, 2015.

[37] M. A. Andrusyszyn, "The Effect of the Lecture Discussion Teaching Method With and Without Audio-Visual Augmentation On Immediate and Retention Learning," Nurse Educ. Today, vol. 10, no. 3, pp. 172-180, 1990.

[38] J. Gralewski, “Teachers' beliefs about creative students' characteristics: A qualitative study," Think. Ski. Creat., vol. 31, no. 1, pp. 138-155, 2019.

[39] J. Lasauskiene and A. Rauduvaite, "Expression of Pre-Service Teachers' Emotional Competency in Their Educational Practice," Procedia - Soc. Behav. Sci., vol. 205, pp. 103-109, 2015.

[40] K. Jauregi, R. De Graaff, and H. van den Bergh, "Learning by doing: Promoting language teacher competencies for networked teaching and learning," Procedia - Soc. Behav. Sci., vol. 34, pp. 116-121, 2012.

[41] N. Zabeli, J. A. Anderson, and B. Saqipi, "Towards Development and Implementation of Learner-Centred Education in Kosovo," J. Soc. Stud. Educ. Res., vol. 9, no. 4, pp. 49-64, 2018.

[42] A. Capelo, I. Cabrita, and M. Lucas, "Crossing Boundaries: Teacher Trainers and Science Curriculum Implementation in East Timor," Procedia - Soc. Behav. Sci., vol. 186, pp. 238-247, 2015.

[43] J. A. Wilson, A. H. Pegram, D. M. Battise, and A. M. Robinson, "Traditional Lecture Versus Jigsaw Learning Method For Teaching Medication Therapy Management (MTM) Core Elements," Curr. Pharm. Teach. Learn., vol. 9, no. 6, pp. 1151-1159, 2017.

[44] N. Sanaie, P. Vasli, L. Sedighi, and B. Sadeghi, "Comparing The Effect of Lecture and Jigsaw Teaching Strategies on The Nursing Students' Self-Regulated Learning and Academic Motivation: A Quasi-Experimental Study," Nurse Educ. Today, vol. 79, pp. 35-40, Mar. 2019.

[45] R. Amran, F. Yokoyama, and K. Nishino, "Development of Active Learning Methods Of English in Japanese High Schools to Support Student Activities in Group Discussions," Procedia Comput. Sci., vol. 96, pp. 1471-1478, Sep. 2016.

[46] S. Şengül and Y. Katranci, "Effects of Jigsaw Technique on Mathematics Self-Efficacy Perceptions of Seventh Grade Primary School Students," Procedia - Soc. Behav. Sci., vol. 116, no. 2006, pp. 333-338, 2014.

[47] S. Papadakis, "Evaluating pre-service teachers' acceptance of mobile devices with regards to their age and gender: A case study in Greece," Int. J. Mob. Learn. Organ., vol. 12, no. 4, pp. 336-352, 2018. 